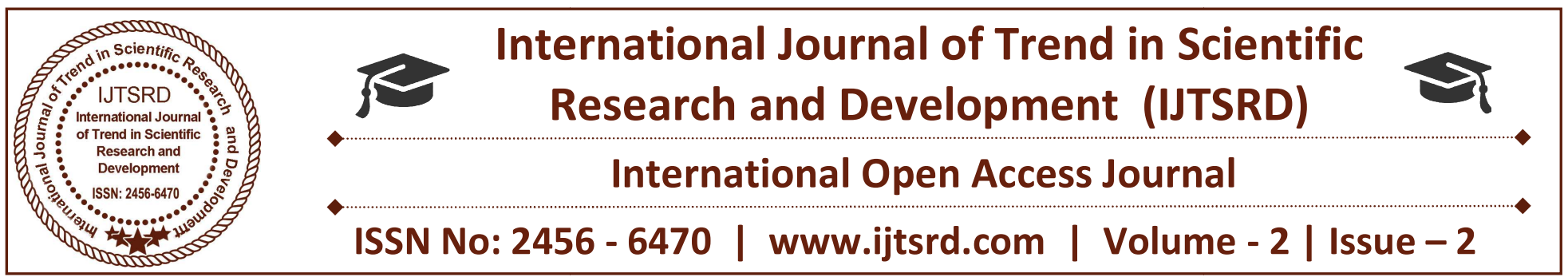

\title{
India in Making as A Powered Nation: A Concept
}

\author{
Narayan Guchhait \\ Teacher of English, Magrahat College, \\ West Bengal, India
}

\section{ABSTRACT}

The $21^{\text {st }}$ century in the world political, social, economic, scientific development is a prime subject to the thinker-politicians and scholars who try to find out various impediments as well as interruption imposed upon new nations or inferior nations. Before and after the Industrial Revolution in Europe a frantic zeal propels to the different nations in Europe searching sphere of trade where they can involve in it and predominate the field. For this purpose of business as well as commercial interest they established, at first, commercial imperialism that after turned into political imperialism or colony; such sort of scenario was very common among different European nations who approached to the race of making imperialism. A competitive attitude to imperialism was observed mainly between two European nations - The English and The French. Other nations like The Ditch, The Portuguese, and The Germans, following the trend, came forward for the race. Before the World War-I England and French were the powerful nations in that time and fortunately England possessed near about one-third of the total world as making Colony as well as Imperialism. That time was passed; political imperialism also had been gone away with the end of the World War-II.

The colony that was a lively theme and used much, has, now changed to be new mode of subject. After colonial era the Globe was divided into two parts or groups: one is the American Group symbolized the Centre of Capitalism and the rest the Russian Group symbolized the Socialism; the Head of the two Groups were engaged in the Cold War what lasted till the demise of the former USSR. Since India has de- chained from colony of the British and established itself to be an independent nation plays its role as a democratic and polyfidelitous progenitive country on multism including religion, race, tribes, language, culture and civilization based on peace loving humanism and coexistence among nations in the world without direct involvement in either the American Group or the Russian Group. But several circumstances in the Global Politics and the Internal Politics make the country to be a responsible country in the field of economics, diplomacy, bilateral cooperation among neighbouring countries, internal securities, culture and many others; India is, now, a leader in the third World Nations after China; it is because India has much human resources, technological advantages, agricultural and industrial progress.

Keywords: Commercial Imperialism, Political Imperialism, Peace, Cold War, Bilateral Cooperation, Cultural Ferociousness

\section{INTRODUCTION}

India is a multicultural nation in the world and becoming a multicultural nation and at the same time larger democracy of it establishes its role in the global politics. After the Independence, the first prime minister of the country followed Non-alignment Policy and the fellow nations who separated from the chain of colonial empire, against the two Blocks The Capitalistic Block and The Socialistic Block during the Cold War. During this time India's role as a leader in the secular group becomes fruitful in that 
contemporary world scenario. The two Blocks tried to impress having motivated either the Capitalism or the Socialism. World political aspect was changed from the end of the World War -II to the $6^{\text {th }}$ decade of the century. After the number of undulation the former USSR, the head the Socialistic Block pacified to the Indian thought what then India was followed by maxims of Peace. And after the collapse of the USSR America becomes only a superpower in the global politics. Now such perception is being changed. However India's role as a power in the global politics turns into a subject of discussion in the context at present. India's role as power may be stressed in two ways - the first is from the internal point of view or national discussion and other is the international point of view or external point of view or discussion. The first point is related to the inner security, development of social, political, economic and native as well as regional culture and civilization. The external point is associated to its relations among neighbouring nations and the development of diplomacy among other nations in the Globe.

Culturally India is only one nation in the World where the cultural deviation is prominent at present. Being a multifarious country it has number of languages spoken by different sects of people. My primary aim of my paper would be,

1. To show why cultural aspects are important to India growing to be a powered nation.

2. Want to emphasise its importance in the world.

3. India's role in the spiritual World builds the nation to be a leader.

4. Side by side I try to show how India is trying to be self-dependent in the view of security (both Internal and External), building materials (related to commodities and war etc.

\section{OBJECTIVE OF THE STUDY}

Making in India is a newly oriented term what emblems criteria produced to be a position in the world where nationally as well as internationally acclaims its recognition with some elements cognate to power. I emphasis India as a making powered country from the several measures like [a] Geography and geographical position or Strategic Position, [b] Population and Demography, [c] Natural Resources that provide a country to be a making nation, [d] National Character and Ideology (peoples and their believes, cultural side and civilization all entwined to one country's status that lead to make), [e] Popular support and proper leadership (one country's global status depend on the two concepts i.e., mass acceptance and skilful leadership lead a country for achieving its goal.) Indian leaders in this respect try its best with the prime support of the country's people. [f] Technology and Military strength (the more prominent measure to be a powerful country). The power of a country depends on its military strength and progress. These several concepts are essential to a country for making. People are a great power of a country. In our country at present there are more than 110 crore peoples in which the majority of peoples are labourers (both organized and unorganized labourer). In 1999 India had total 28,60,0000 labourers congregated with 9.4\% of organized labourer and $90.6 \%$ of unorganized labourers. The picture was changed in 2001. There was total number of labourers near about 40 crore in which $7 \%$ of organized labour and $93 \%$ of unorganized labour were estimated. However I want to show my aims and objectives regarding the concept in the paper from both criteria enhancing power in making and cultural point of view:

a. To establish how the elements of power are implicit to India as in making to be powered;

b. To express the view that India is making herself to be recognition in the view of self-dependent attitude;

c. To show the culture and how it is related to making in India;

d. "To explore how the ancient practices like Yoga, and Spiritual Idealism etc. are related to this view.

\section{WAYS AGAINST DIFFICULTIES}

To describe about the internal aspect we can stress social conditions that are closely associated to the development of man and society. There are number of problems like gender discrimination problem (that is according to Urban Unemployment in India Pacific Affairs $(60 \%$ of male and $40 \%$ of Female per 1000 male), security problem, unemployment problem, and problem of poverty, religion and many more. Over the 70 years back after the Independence such said problems are still present. Though various programmes have been taken for the salvation of these but a new trend is felt in our heart to be globalized, to be benevolent. We can say the Govt. initiative to the cut of Budget amount for example, subsidy on food for the poor section of society by the reimplementation of ration system. Subsidy on crude 
oil and agricultural product and even in the implementation of Bardhakya Bhrata, vision of the building aid for the poor sections etc. has been implemented to drive away poverty. Besides these, literacy in India is gradually increased if we compare the present literary rate to the previous censuses. In 2000 the literacy rate of the country was $68.84 \%$ and in 1991 and 1981 the rate were respectively $52 \%$, $62 \%$. Illiteracy and poverty in our country go hand in hand and that is a common picture in all the underdeveloped countries of the World. In India the special states like Bihar and Uttar Pradesh have highest score of poverty and illiteracy rate comparatively to the other states in the country. So we see how the illiteracy is contained issue in our society as a problem. Various State Govt. and Central Govt. of course, take active step to remove various crises arisen in society. Govt. takes different measures for the removing of poverty and unemployment problem in villages as well as towns. In village the adopted several programmes related to this are:

1. Community Development Programme (SDP) in 1952.

a. Small Farmers Development Agency (SFDA)

b. Marginal Farmers and Agricultural Labourer Agency (MFAL)

2. Integrated Rural Development Programme(IRDP) in $1976-77$

a. Training of Rural Youth for Self Employment (TRYSE)

3. National Rural Employment programme (NREP) on $2^{\text {nd }}$ October, 1980

4. Rural landless Employment Guarantee programme (RLEGP) on $2^{\text {nd }}$ October, 1980

a. Food for Work programme

5. Jawahar Rojgar Yojana (JRY) in 1989 certified to ensure of job for 50-100 days works in which $30 \%$ would be preserved for women.

6. Jawar Gram Samridhi Yojana (JGSY) in 1999 aim to produce durable as well as productive assets

7. Swarnajayanti Gram Swa RojgarYojana (SGSY). In 1999 two schemes like DWCRA and MWS (Million Well Scheme) are added to it.

8. National Rural Employment Guarantee Act (NREGA) in 2005.

Like Village in town the adopted several programmes related to this are:

1. Self-Employment programme for the Urban poor (SEPUP) in 1986

2. Nehru Rojgar Yojana (NRY) in 1989
3. Prime Minister's Rojgar Yojana (PMRY) in 1993-94

4. Swarnajayanti SahariRijgar Yojana (SSRY) in 1997

a. Urban basic Services for the Poor

b. Prime Minister's Integrated Poverty Alleviation programme (PMIPAP)

\section{NEIGHBOURHOOD POLICY}

India's relationships to its neighbouring countries make, of course, distinctive impression in the way of making India to be a powered nation. India's relationship to the countries like Bangladesh, Sri Lanka, Afghanistan, Bhutan, China, Myanmar, and Maldives is friendly. Pakistan the neighbouring country to India often creates proxy war against India and tries to make restless the country to be involved in war against Pakistan imported terrorism in Jammu and Kashmir. Prime minister (from previous to Present) of India they try to build a friendly relationship to the country. Besides Pakistan other neighbouring nations to India produce friendly relation in the field of infrastructural development, education, culture and commerce and donor aided nation. These attitudes propel India to be a making nation. India's Look East Policy and implementation of Liberal Economic System and amalgamation to the alliance of either Socialism or Capitalism that is in picture of Mix-Economic Policy create an immense significance. But the recent development of friendly ties with America after the collapse of the former USSR India's role in the Global Politics is exquisite. Now powerful and developed nations give importance to the country. It is, because after the collapse of the USSR America gives and appreciates India's role in the establishment of democracy, culture, peace loving idiosyncrasy and any sort of universal problems among nations.

\section{SELF HELF ATTITUDE}

India's role to be self-dependent what we see in the reign of Indira Gandhi, Nehru and even the reign of Chandra Shekhar, they depend something on foreign aid. And the foreign policy of the country of that time was regulated according to these. Now such situation is changed. Our Policy Maker in this respect more conscious for making good feeling among neighbouring nations and in the entire universe. India's role for self-dependence becoming a powered nation what is seen in its up gradation of relationship among nations in the globe educationally, 
commercially, culturally and in the field of leadership. Being a multicultural nation India tries to enrich partially the cultural relation to Bangladesh, Afghanistan, Sri Lanka, Nepal and Maldives. Culturally there are much similarity between India and Bangladesh where Bengali culture and civilization is common. The cultural trend between India and Afghanistan particularly Islamic culture is observed; with Sri Lanka there is found Tamil culture and culture of Buddhism. But Nepal is different because there is a much similarity between them. Bhutan and Myanmar the two nations culturally correlated in the field of tribal as well as Buddhist Culture.

\section{ATTITUDE OF A POWERED NATION}

India is making himself to be a power in the field of arms and weapons what acclaimed to be selfdepended. Earlier weapons and arsenal were imported from Russia, French, UK, and Palestine but now India produces these with his own technology. In the field of research the concept Making in India is quite common. Research scholars now are engaged in the various laboratories not only in India and outside of the country too. The contribution in Space-Research work, technology, science and humanistic ground are the remarkable example to the contribution of these fields. India's craft full mission to moon, to mars and launching satellite in the space and many others propel ISROs scientists approaching to the level of NASA and ESRO. In the making of weapons India is trying to be self-depended as par as possible and with the use of native techniques and technology India builds War related instruments enriching Military power mentioned below:

1. Intermediate Range Ballistic Missile (IRBM) regarded as Long Range Missile
a. Agni-I (Range $1200-2000 \mathrm{KM})$
b. Agni -II (Range $2000-2500 \mathrm{KM}$ )

2. Surface to Surface Missile (SSM) or Battlefield Missile or Short Range Missile

a. Prithi - (Range 250KM)

3. Surface to Air Missile (SAM) in this stage India has entered one into three countries in the world.

a. Trishul

4. Anti-Tank Missile (called Fire and Forget Missile)

a. Nag (Range 4KM)

5. Multi-Target Missile (MTM), Range 25KM

a. Dhanush

6. Ship to Ship Missile (SSM)

a. Pralay Missile Boat (Range - $150 \mathrm{KM}$ )
7. Brahmos (Supersonic Cruise Missile)

8. Tajas(Light Combat Aircraft)

9. Netra (Aorborn Early Warning and Control Aircraft or AEWCA)

10. Various Battle Ships built with India's own Technology.

\section{COMMUNIAL INTEGRITY}

India is a leadership country among the third world countries. After the World War - II the process of decolonization was began to establish independent state for the development of the nation and race for the existence of community as well as races it is required to construct a state where the elements of progress cognate to race and community would be coexisted inseparably to the process of making and constructive nation. As India in the global politics has been treated as dominating or leading country in the third world is entwined with number of problems that produce crises for the unity and integrity for the nation to resist it. Since the Independence to the present day such trend becomes more crucial and deeply enrooted. India is a multicultural state based on emotional integration. The spiritualistic spirit among the Indian Community play, of course, a vital role not only in the country within but also to the other countries in the world.

\section{ECONOMIC GROWTH}

On 22 September, 2005 a report was published in which powerful countries were shown according to their Gold Reserves in their respective Central Banks. In this report from the very analytical point view we can say that as a powered nation India's position is nearly to china and above the other developing and underdeveloped countries.

\begin{tabular}{|l|l|}
\hline Name of Country & $\begin{array}{l}\text { Reserved Gold } \\
\text { (in Ton) }\end{array}$ \\
\hline USA & $8,133.5$ \\
\hline Germany & $3,427.8$ \\
\hline IMF & $3,217.3$ \\
\hline France & $2,982.6$ \\
\hline Italy & $2,451.8$ \\
\hline Switzerland & $1,290.1$ \\
\hline Japan & 765.2 \\
\hline Nederland & 722.4 \\
\hline European Central Bank & 719.9 \\
\hline China & 600 \\
\hline & \\
\hline
\end{tabular}


International Journal of Trend in Scientific Research and Development (IJTSRD) ISSN: 2456-6470

\begin{tabular}{|l|l|}
\hline India & $557^{1} *$ \\
\hline Spain & 493.3 \\
\hline Taiwan & 423.3 \\
\hline Portugal & 407.5 \\
\hline Russia & 386.6 \\
\hline Pakistan & 65.3 \\
\hline Kazakhstan & 58.6 \\
\hline
\end{tabular}

following chart where India's position is comparatively shown below:

\begin{tabular}{|c|c|c|c|}
\hline $\begin{array}{l}\text { Bank } \\
\text { Name }\end{array}$ & Country & $\begin{array}{l}\text { Capital } \\
\text { Value(Milli } \\
\text { on Dollar) }\end{array}$ & $\begin{array}{l}\text { Asset } \\
\text { Value(Milli } \\
\text { on Dollar) }\end{array}$ \\
\hline $\begin{array}{l}\text { C.T. } \\
\text { Group }\end{array}$ & $U S A$ & 66,871 & $12,68,032$ \\
\hline $\begin{array}{l}\text { Credit } \\
\text { Agricultur } \\
\text { e Group }\end{array}$ & France & 55,435 & \\
\hline $\begin{array}{l}\text { H.S.B.C. } \\
\text { Holding }\end{array}$ & $U K$ & 54,863 & \\
\hline $\begin{array}{l}\text { Mijuho } \\
\text { Financial } \\
\text { Group }\end{array}$ & Japan & & $12,85,471$ \\
\hline U.B.S. & $\begin{array}{l}\text { Switzerlan } \\
d\end{array}$ & & $11,20,543$ \\
\hline $\begin{array}{l}\text { Industrial } \\
\text { and } \\
\text { Commerci } \\
\text { al bank }\end{array}$ & $0_{0}$ & & $6,37,829$ \\
\hline $\begin{array}{l}S B I^{2} \\
a I^{\prime} \text { our }\end{array}$ & $\begin{array}{l}\text { India } \\
\text { nall }\end{array}$ & $5,262.90$ & $\begin{array}{l}41,33,633.3 \\
8\end{array}$ \\
\hline
\end{tabular}

In India Economic Growth Rate in 2005-06, 2006-07, 2007-08, 2008-09was respectively 9.4\%, 9.6\%, 9\%, \&.6\%. World Economic Growth Rate according to Gross Domestic product or GDP in 2007, 2008, 2009 is respectively $5.7 \%, 3.7 \%, 2.2 \%$ and UK in 2007 and 2008 is respectively $3 \%, 8 \%$; Japan's growth rate at the same time was near about 0 . In the Euro zone in 2007 and 2008 the economic growth was respectively $2.6 \%, 1.2 \%$ and our neighbouring country, China the economic growth rate in 2007, 2008, 2009 was $11.9 \%, 9.7 \%, 8.5 \%$ respectively; whereas OECD (Organization for Economic Cooperation and Development) consist with 30 Developed Country like Britain, Canada, Korea, France America the growth rate of this organization in 2007 and 2008 was $2.6 \%$ and $1.4 \%$. India is a developing country in the view of economic growth rate. Number of Millionaire (who have 10 lacks Dollar Assets) as well as Billionaire (who possessed 100 ceros) in India also exposes it position in the world economy are 83,000 and 36(in 2007)whereas USA is 341, Germany 57, Russia 27, Japan 24, UK 24, Hong Kong 15 and so on The above statement is according to a Report reported on March, 2005.Per head expenditure of the Indian people is, of course, pointed out to show how much money they expend. In $1999-2000$ the average expenditure of Indian people was Rs. 327.56 and whereas per head expenditure in Kolkata was on average Rs 374.79. The Telegraph on the 23rd February, 2001 had shown estimation on per head expenditure that is given below:

\begin{tabular}{|l|l|l|}
\hline Name of States & $\begin{array}{l}\text { Village } \\
\text { (as Daily Rs) }\end{array}$ & $\begin{array}{l}\text { Town } \\
\text { (as Daily Rs) }\end{array}$ \\
\hline West Bengal & 350.17 & 409.22 \\
\hline Maharashtra & 318.63 & 539.71 \\
\hline
\end{tabular}

In the Banking system India is also developed according to Tire Capital-I, journal in London. It is presented according to assets of Banks in the

\section{CULTURAL ASPECTS}

The Language in the field of global significance something is also related on power states. USA is now a powered nation; the English especially American English becomes used as primary communication makes problems what English people claim now. When England was a powered nation their language in this sense plays such role globally. We see French language Portuguese language in the colonial period plays their respective role. During the cold war period Russian Language claimed to be a world language being a super power at that time in the world. But at recent time, in the age of Globalization Chinese, Japanese, Hindi, Malayalam may have claimed in this respect to be progressive language. So we see when a nation or race is technologically, financially developed, its culture and civilization automatically accepted by other races or nations. Economic growth, technological development, progress of Science and Democracy, and Policy and Diplomacy of nations or race treated as standard used as usual.

\footnotetext{
*India purchased 200Ton Gold from the Reserve Bank of International Monetary Fund on 19th October, 2009. At present the Reserved Gold of the Central bank of India is 557 Ton.
}

\footnotetext{
${ }^{2}$ On $1^{\text {st }}$ April ,2017 five associate banks ( State bank of Bikaner, State Bank of Travancore, State bank of Patiala, State bank of Hyderabad, State Bank of Mysore) Bartaman $-7^{\text {th }}$ March, 2017, P. --3
} 
a. The Culture of a country exposes its recognition and acceptance to all. India is a multilingual and cultural nation. There are various peoples with their language and religion in our country. Culture what establishes India probe a special recognized nation by the other countries in the world is its religion based on the view of Hinduism preached by missionaries like Bharat Sebasram Sangha, Ramakrishna Mission, Satsangha Asrama and many others raised Indian Philosophy on humanism to the several parts of the world. They are making their attempts constantly on the view of Vedas, Upanishad, the Gita closely associated with the lives of Indian people to the Global Platform.

b. Indian Music and dance regarded as classical is, of course, another stepping stone in the threshold of the universal as well as cultural community Great Musicians of classical Music on Vocal and Instrumental contribute their achievement that leads India as a culturally motivated country. Vocalists like Golum Ali Khan, Zakir Hossein, Gouri Sankar and Sater players like Anusksha Sankar and many more sustain image of Indian Culture to the world. Besides, Indian Yoga practice is one of the antique practices in India shows the key essence to the World because it has spirit of reducing tension. It is in the words of Michael Nicholson:

'When cultures come into contact, there is going to be some mixing. Normally the bigger dominant culture is going to influence the smaller more than the other way round.

c. In the field of research particularly in the scientific research number of Indian students from IIT or common institutions are, now, engaged in the various parts of the World. Meritorious students in the field of IT Sector are employed that show how India is becoming a power. The cultural heritage of India influences its neighbouring Countries too. In the educational sphere as IIT students who are employed in the various sectors exposes the country's image to the universe; what shows how India has developed its role to be made as a power and at the same the Indian Universities and Colleges and their students specially in the field of research go away to the foreign land where they are engaged in their respective area. At present $25 \%$ of Indian students of Engineering and $15 \%$ of students of Accountants are, now, entwined in the several international institution what shows how the Indian Universities and colleges are estimated with the view of excellence that produce enthusiasm to learners to prefer getting job in the outward country.

d. The Cultural ties to Bangladesh, Nepal, Sri Lanka and even Afghanistan are appreciated. Some may point out as asymmetry but it is sometimes based on racial relationship in that the dominance of dominant culture is found in the sphere of film, music, language, technology, economic and security. It is noted that when a country is in power the language as well as culture of the particular country becomes to be a subject of imitation in this regard and the culture as well as language of the specific country is regarded as standard language and culture. However, Indian Language as well as culture specially the national language, Hindi, is, now, accepted as a major language spoken by the majority of people in India. The UNESCO also feels the dominancy of the language beyond the territory of the country.

\section{CONCLUSION}

India is growing to be a powerful country and it makes itself to develop the social, economic, security related problems, keeping friendship among neighbour as well as other nation. It is a great responsibility in the world Politics where our country like India as larger democracy plays it role not only as making itself but also to lead to be a responsible leader. Though there are number of problems in our country from the developing and infrastructural point of view the country tries gradually to solve these. Being a larger democracy in the world and at the same a developing one the nation is approaching to achieve its goal. There are number of measures regarding a making nation as well as a powerful country. But cultural sides are more important and vital forthe development of humanism, peace loving attitude with removing any sort of barrier. Indian thought cognate to spiritual philosophy, Music, Yoga Practice, Education of Science and Technology, Commerce and Humanistic and so on propel culturally a making image to the level of agape prosperity and universal recognition. 
International Journal of Trend in Scientific Research and Development (IJTSRD) ISSN: 2456-6470

\section{REFERENCES}

1. Anderson, Stephen R., Languages( A Very Short Introduction). U. K: OUP 2012.

2. Basu, Major D. K., Defence and Strategic Studies. Kolkata: Ankish Publication, 2010.

3. Bhattacharya, Tapan Kumar, Kalo Taka O Haola. Kolkata: Progressive Publication, 2010.

4. Chatterjee, Aneek, Asian Politics. New Delhi: Pearson, 2012.

5. Chatterjee, Aneek, International Relations Today (Concepts and Applications). New Delhi: Pearson, 2010.

6. Chaudhuri, Chattapadhyay and Ghosh, BharaterSamajikSamasya. Kolkata: Chatterjee Publishers, 2008.
7. Ghosh, Nirmalkrinti, Indian Politics and International. Kolkata: Sri Bhumi Publishing Company, 2000.

8. Ghosh, Peu, International Relations. New Delhi: PHI Learning Private Limited, 2011.

9. Ghosh, Roy and Mitra, BharateKaloTakarKaloArthanity. Kolkata: GranthaMitra, 2010.

10. Jana, Narayan Chandra, International Economy and Indian Economy. Kolkata: Suhrid Publication, 2002.

11. Kjhasnabish, Ratan, Biswayan O Bharatbarsha. Kolkata: Progressive Publishers, 2005.

12. Nicholson, Michael, International Relations (A Concise Introduction). U.K.: Palgrave Macmillan, 2005.

13. Tharoor, Shashi, Pax India. New Delhi: Penguin Books, 2013. 